\title{
Ligand-activated PPARס expression promotes hepatocellular carcinoma progression by regulating the PI3K-AKT signaling pathway
}

\author{
Wei Han ${ }^{1}$, Nan Wang ${ }^{1}$, Rui Kong ${ }^{1}$, Wen Bao ${ }^{1}$ and Jie Lü ${ }^{2 *}$
}

\begin{abstract}
Background: Peroxisome proliferator-activated receptor-beta/delta (PPARS) was considered as the key regulator involved in the evolution of various tumors. Given that PPAR $\delta$ potential role in hepatocellular carcinoma (HCC) is still obscure, we comprehensively assessed its expression pattern, prognosis, functions and correlation with tumor microenvironment in HCC using public database data and in vitro studies.

Methods: Transcriptional data and clinical data in the TCGA and GEO database were analyzed in R software. Quantitative real-time polymerase chain reaction (qRT-PCR), western blotting and immunohistochemistry were used to detect the expression level of related RNA and proteins. The malignant biological characteristics were explored by cell counting Kit-8 (CCK8), 5-Ethynyl-2'-deoxyuridine (EdU) assay and wound healing assay.

Results: Our results illustrated that PPAR $\delta$ expression was significantly higher in HCC tissues and HCC cell lines. Elevated expression of PPAR $\delta$ suggested poor clinical staging and prognosis in HCC. Ligand-activated PPAR $\delta$ expression promoted the proliferation and invasion of HCC cells via PDK1/AKT/GSK3 $\beta$ signaling pathway. The expression of PPAR $\delta$ was closely related to the HCC tumor microenvironment.
\end{abstract}

Conclusions: PPARS plays an important part in HCC progression, penetrating investigation of the related regulatory mechanism may shed light upon further biological and pharmacological value.

Keywords: PPARS, HCC, Prognosis, PI3K-AKT

\section{Background}

Hepatocellular carcinoma (HCC) has become an important malignant disease threatening the people health around the world. In the latest global cancer statistics report in 2020, the incidence of HCC was 4.7\% (the seventh place), and the mortality rate was $8.3 \%$ (the second place) [1]. Although the popularization of the hepatitis $B$ vaccine and the development of multiple therapeutic methods enhance the curing possibility, the number of deaths related to $\mathrm{HCC}$ remains massive, since vague

*Correspondence: kennisren@hotmail.com

${ }^{2}$ Department of Gastroenterology, Gongli Hospital of Shanghai Pudong New Area, Shanghai, China

Full list of author information is available at the end of the article symptoms and individual specificity may respectively lead to the difficulty in diagnosis and different sensitivity to drug $[2,3]$. Therefore, more prognostic biomarkers and therapeutic targets need to be dug up.

Peroxisome proliferator-activated receptors (PPARs) are members of the ligand-activated nuclear transcription factor superfamily. The three isoforms of PPAR $\alpha$ (PPARA), PPAR $\delta / \beta$ (PPARD), and PPAR $\gamma$ (PPARG) are distributed in different organs and participate in a variety of energy metabolism processes $[4,5]$. Activated by endogenous ligands, including fatty acids and derivatives or synthetic modulators, they form heterodimers with retinol X receptors (RXR), which bind to PPAR response elements (PPRE) upstream of the target gene promoter and finally regulate the transcription of target genes $[6$, 
7]. There has been increasing recognition of the crucial role they played in tumor progression. PPAR $\alpha$ and PPAR $\gamma$ can affect the development of malignant tumors by regulating survival, metastasis, energy metabolism, immune response, and cell stemness maintenance, which has been reported in various common solid tumors including colon cancer, lung cancer, breast cancer, hepatocellular carcinoma, and so on [8-13]. PPAR $\delta$ is widely expressed in the human body but is mainly highly expressed in skeletal muscle and macrophage, which acts as a vital regulatory factor in fatty acid oxidation, keratinocyte differentiation and wound healing [14]. PPAR $\delta$ has been found to be differentially expressed in several major human cancers including colorectal cancer, gastric cancer and prostate cancer, and may function as oncogene or tumor suppressor through diverse mechanisms [15-17]. In most of the reported literature, activation or high expression of PPAR $\delta$ has been demonstrated to be related to cell proliferation and tumor growth [18]. Additionally, PPAR $\delta$ was considered to be a key regulator involving tumor metastasis, which strongly enhanced angiogenesis, epithelial-mesenchymal transition (EMT), invasion and migration [19, 20]. Currently, there have been controversial opinions regarding its relationship with tumor development due to the specificity of tumor types. Given the limited research on the biological functions of PPAR $\delta$ in HCC, multi-dimensional analysis was used to investigate the expression pattern, prognostic value and biological function of PPAR $\delta$ as well as the relationship with tumor microenvironment (TME) based on resources from public databases and in vitro studies.

\section{Materials and methods}

Microarray data acquisition and differential expression analysis

The transcriptome expression profiles of HCC were downloaded from The Cancer Genome Atlas (TCGA) and Gene Expression Omnibus (GEO) database. We performed differential mRNA expression analysis with "ggpubr" R package in R software (Version 4.0.2).

\section{Cell culture}

Three HCC cell lines, Bel 7402, SMMC-7721, HepG2 and human liver cell line LO2 were obtained from the Cell Bank of Type Culture Collection of the Chinese Academy of Sciences (Beijing, China). Four cell lines were cultured in high glucose Dulbecco's modified Eagle's medium (DMEM, Thermo Fisher Scientific, Waltham, MA, USA) with $10 \%$ fetal bovine serum (FBS, Thermo Fisher Scientific, Waltham, MA, USA). The cells were cultured in a $37^{\circ} \mathrm{C}, 5 \% \mathrm{CO}_{2}$ incubator and were sub-cultured when the cell density reached $90 \%$.
Cells were exposed to different concentrations of PPAR $\delta$ agonist GW501516 (Topscience Co., Ltd., Shanghai, China) or GW501516 and PPAR $\delta$ antagonist GSK3787 (Topscience Co., Ltd., Shanghai, China) for 24-48 h. Morphology changes were observed using a phase-contrast microscope and imaged $(200 \times)$.

\section{Correlation of clinical characteristics and survival analysis}

Clinically relevant data such as age, gender, stage, grade, survival time, and outcome was obtained from TCGA database. The samples were divided into high expression group and low expression group according to the mean value of PPAR $\delta$ mRNA expression. The relationship between mRNA expression and grade, TNM staging was tested in R software (Version 4.0.2). The Kaplan-Meier (K-M) survival curves were drawn by GraphPad Prism 8. Cox regression analysis was performed using "forestplot" and "rms" $\mathrm{R}$ packages in $\mathrm{R}$ software (Version 4.0.2).

\section{Quantitative real-time PCR (qRT-PCR)}

Total RNA was extracted from the cell lines using Trizol reagent (Invitrogen, Carlsbad, CA, USA). The RNA was reverse transcribed into cDNA using the transcription kit from Takara Biotechnology (Dalian, China). qRTPCR was performed in the Applied Bio-systems 7500 Real-Time PCR System using 50 ng of cDNA and a SYBR Green PCR master mix (YEASEN, Shanghai, China). $\beta$-actin was used as the internal control gene. The quantitative level of mRNA was evaluated by the $2^{\wedge-\Delta C t}$ relative quantitative method. The primers were as follows:

$\beta$-actin:

\section{F: CATGTACGTTGCTATCCAGGC R: CTCCTTAATGTCACGCACGAT PPARS: \\ F: CAGGGCTGACTGCAAACGA R: CTGCCACAATGTCTCGATGTC ANGPTL4: \\ F: TGGGACGAGATGAATGTCCTG R: CTGCTGTTCTGAGCCTTGAGTT}

\section{Western blotting (WB) analysis}

The total proteins were extracted from the cell lines using RIPA lysis buffer (Invitrogen, USA). Protein concentration was determined with a BCA kit (Kaiji Biology, Nanjing, China). WB was performed as routine. The primary antibodies were $\beta$-actin (1:5000, 60008-1-Ig, Proteintech, Chicago, USA), PPAR $\delta$ (1:500, 10156-2-AP, Proteintech, Chicago, USA), E-cadherin (1:50, ab1416, abcam, Cambridge, UK), Snail (1:1000, 3879, Cell Signaling Technology, Danvers, MA), VEGFA (1:1000, ab1316, abcam, Cambridge, UK), PDK1 (1:1000, 3062, Cell Signaling Technology, Danvers, MA), p-PDK1(1:500, 3438, Cell Signaling Technology, Danvers, MA), AKT (1:1000, 
C67E7, Cell Signaling Technology, Danvers, MA), p-AKT (1:500, 4060, Cell Signaling Technology, Danvers, MA), GSK3 $\beta$ (1:1000, 22104-1-AP, Proteintech, Chicago, USA), p-GSK3 $\beta$ (1:500, 5558, Cell Signaling Technology, Danvers, MA), Cyclin D1 (1:500, 2978, Cell Signaling Technology, Danvers, MA) and the secondary antibody was horseradish peroxidase-conjugated anti-rabbit (1:500, 7074, Cell Signaling Technology, Danvers, MA) or antimouse IgG (1:500, 7076, Cell Signaling Technology, Danvers, MA). The relative band intensities of PPAR $\delta$ were calculated using the Odyssey Two-color Infrared Laser Imaging System (Li-Cor, Lincoln, NE).

\section{Tissue samples acquisition and immunohistochemical analysis}

Paraffin biopsies of HCC tissues and paracancerous tissues from 4 patients were obtained from the Shanghai Tenth People's Hospital. This study was approved by the human study ethics committees at Shanghai Tenth People's Hospital. All patients provided written informed consent for participation in the study. Specimens were handled in accordance with legal and ethical regulations.

The paraffin sections were washed twice in xylene, and then soaked in anhydrous ethanol, anhydrous ethanol, $85 \%$ ethanol, $75 \%$ ethanol, and distilled water in sequence. Next, the sections were added with citric acid antigen repair solution, baked in the microwave oven and washed with phosphate buffered saline (PBS) after cooling. $3 \%$ hydrogen peroxide solution was added to the slices to block peroxidase, incubated in the dark at room temperature and washed with PBS. After blocking the sections with $3 \%$ bovine serum albumin (BSA), drop the primary antibody prepared in an appropriate proportion onto the sections and incubate overnight at $4{ }^{\circ} \mathrm{C}$ in a humidified box. The primary antibody that we used was PPAR $\delta$ (1:200, 10156-2-AP, Proteintech, Chicago, USA). The secondary antibody diluent of the corresponding species of the primary antibody was added dropwise to the sections, and incubated at $37^{\circ} \mathrm{C}$. Next, the sections were stained with $\mathrm{DAB}$ color developing solution and hematoxylin, respectively. Finally, the sections were dehydrated in $75 \%$ ethanol, $85 \%$ ethanol, anhydrous ethanol, anhydrous ethanol, n-butanol, xylene, and sealed with neutral gum after drying. The sections were observed by optical microscopy. The integrated optical densities (IODs) of the PPAR $\delta$ were calculated using Image-Pro Plus software 6.0 (Media Cybernetics, Silver Spring, MD, USA).

\section{Cell counting kit-8 (CCK8) assay}

Two HCC cell lines, Bel 7402 and SMMC-7721, were plated in 96-well plates at a density of $2 \times 10^{4}$ cells/ $\mathrm{ml}$. After the cells were incubated for $24 \mathrm{~h}$, the medium was replaced with DMEM containing PPAR $\delta$ agonist GW501516 or GW501516 and PPAR $\delta$ antagonist GSK3787. After $48 \mathrm{~h}$ of drug intervention, the cells were treated with the CCK8 kit (YEASEN, Shanghai, China) and detected of the absorbance (OD) values at $450 \mathrm{~nm}$ using microplate reader (Synergy H4, BioTek, Winooski, VT, USA).

\section{5-Ethynyl-2'-deoxyuridine (EdU) assay}

Bel 7402 and SMMC-7721 cells were inoculated into 6-well plates containing glass microscope slides. GW501516 or GW501516 and GSK3787 were added to each cell line after $24 \mathrm{~h}$. After $48 \mathrm{~h}$ of drug action, the cells were washed with PBS, fixed with $4 \%$ paraformaldehyde, and incubated with glycine. Add $100 \mu \mathrm{l}$ of penetrant $(0.5 \%$ TritonX-100 in PBS) to each well and incubate on a rocker device for $10 \mathrm{~min}$, then add $100 \mathrm{ul}$ of $1 \mathrm{X}$ Apollo $^{\circledR}$ staining reaction solution and incubate for $30 \mathrm{~min}$ at room temperature and protected from light. Next, the cells were washed sequentially with $100 \mu \mathrm{l}$ of penetrant and $100 \mu \mathrm{l}$ of methanol. The removed slides were washed three times with PBS in a rocker device. After that, the DAPI dye solution was added dropwise to stain the nucleus at room temperature for $10 \mathrm{~min}$, kept in dark place. Finally, the slides were mounted with antifade mounting medium. Fluorescent microscopy was used for microscopic observation and image collection.

\section{Wound healing assay}

Bel 7402 and SMMC-7721 were inoculated on a 6-well plate, scratched with a $200 \mu$ l pipette tip when the cells were $80-90 \%$ confluent, washed with PBS and then cultured in $1 \%$ low concentration serum containing GW501516 or GW501516 and GSK3787. The results were analyzed using Image J software, the healing rate was quantified by calculating the gap size.

\section{Immunological analysis}

CIBERSORT tool can calculate the immune cell compositions using gene expression profiles [21]. We measured the infiltration of 22 types of immune cells in HCC samples by CIBERSORT, and further evaluated their relationship with PPAR $\delta$ expression. All processes were carried out in R software (Version 4.0.2).

\section{Statistical analysis}

Student's t-test was used for two-group comparisons, one-way ANOVA was used for multigroup comparisons. The Kaplan-Meier survival curves were drawn based on log rank test. Univariate and multivariate analysis were performed using the Cox regression analysis model. 
Spearman test was used to verify the correlation between 22 kinds of immune cells content and gene expression. All data analysis was performed in SPSS 21.0 software. The criterion of significant difference is defined as $p<0.05$.

\section{Results}

\section{Elevated expression of PPARס in HCC tissue and HCC cell}

We acquired 424 transcriptome files (374 HCC samples and 50 normal samples) from the TCGA database and 631 transcriptome files (391 HCC samples and 240 normal samples) from the GEO database. The results suggested that PPAR $\delta$ expression was significantly higher $(p<0.05)$ in HCC tissues than in normal tissues at the transcriptional level (Fig. 1A and B). Immunohistochemical analysis showed that PPAR $\delta$ was highly expressed in HCC tissues but was weakly positive in adjacent tissues $(p<0.001)$ (Fig. 1C). In in vitro experiments, the expression of PPAR $\delta$ in Bel 7402, SMMC-7721 and HepG2 cells was significantly higher than that of $\mathrm{LO} 2$ cells, which was confirmed by qRT-PCR and WB (Fig. 1D and E).

\section{Association of PPARס expression and clinical characteristics} The clinical files of 377 patients downloaded from the TCGA database, including age, sex, clinical stage, lymph node status, distant metastasis, pathology classification, were presented in Table 1. As shown in Fig. 2, the expression level of PPAR $\delta$ was elevated while the clinical staging and grading of tumor progressed (Fig. 2A, B and C). Among them, the number of stage IV, T4, and G4 patients may be too small to be of statistical value. These results revealed that PPAR $\delta$ may affect the progression of HCC. Kaplan-Meier survival curves were drawn to investigate the relationship between the expression of PPAR $\delta$ and various clinical outcomes. High PPAR $\delta$ expression predicted poorer over survival (OS) (Fig. 2D), progression free survival (PFS) (Fig. 2E) and disease specific survival (DSS) (Fig. 2F) in patients with HCC. Besides, Cox regression analyses suggested that PPAR $\delta$, PI3K, PDK1, AKT1 were risk factors for poor prognosis of $\mathrm{HCC}(\mathrm{HR}>1)$ (Fig. $2 \mathrm{G}$ and $\mathrm{H})$.

\section{PPARס promoted HCC cell proliferation}

The cell proliferation ability was evaluated using the CCK8 kit and EdU assay. GW501516 is an effective and highly specifc PPAR $\delta$ agonist [25]. GSK3787 could antagonize ligand-induced expression of PPAR $\delta$-dependent genes, but it does not antagonize basal expression of these genes [26]. GW501516 increased mRNA expression of PPAR $\delta$ target gene Angptl4 while GSK3787 reversed its up-regulated expression, which suggested that GW501516 activated the expression of PPAR $\delta$ and GSK3787 antagonized the activation (Fig. 3A and B). The HCC cell lines, Bel 7402 and SMMC-7721, were treated with GW501516 $(1 \mu \mathrm{M}, 10 \mu \mathrm{M}, 15 \mu \mathrm{M})$ for $48 \mathrm{~h}$. The CCK8 results revealed that PPAR $\delta$ agonist promoted HCC cells proliferation in a dose-dependent manner (Fig. 3C and D), and GSK3787 reversed the proliferation effect of GW501516 (Fig. 3E and F). In the EdU staining assay, the intervention of GW501516 $(15 \mu \mathrm{M})$ significantly increased the ratio of proliferating cells compared to control groups, and GSK3787 $(10 \mu \mathrm{M})$ reversed the effect in Bel 7402 cell line (Fig. 3G and I) and SMMC7721 cell line (Fig. $3 \mathrm{H}$ and J). Taken together, ligand-activated PPAR $\delta$ enhances the proliferative capacity of HCC cells.

\section{PPARס promoted HCC cell migration, EMT and angiogenesis}

Cell migration was measured using wound healing assay. The healing percent of the GW501516 treatment group was greater than that of the control group and GSK3787 abolished the effect (Fig. 4A and C).

We examined whether PPAR $\delta$ activation had a positive effect on EMT and angiogenesis by measuring the expression of EMT-related markers and VEGFA. GW501516 reduced the expression of E-cadherin, increased the expression of Snail and VEGFA, the antagonist abolished the expression changes (Fig. 4B and D). Taken together, ligand-activated PPAR $\delta$ facilitate migration, EMT, and angiogenesis in HCC cells.

\section{PPARס partially activated PI3K-AKT signaling pathway} Literature has shown that the carcinogenesis of PPAR $\delta$ was related to the activation of the PI3K-AKT pathway $[22,23]$. Therefore, we detected the expression of proteins related to the PI3K-AKT pathway in different treatment groups of HCC cells. The results revealed that GW501516 intervention up-regulated the expression of p-PDK1, AKT, p-AKT, and its downstream effector

\footnotetext{
(See figure on next page.)

Fig. 1 Differential expression of PPAR in HCC tissue and HCC cell line. Bioinformatics analysis suggested that PPAR $\delta$ expression was significantly $(p<0.001)$ higher in HCC than in normal tissues based on TCGA database and GEO databases $(\mathbf{A}, \mathbf{B})$. Immunohistochemical analysis of 4 HCC tissues showed that PPARS was highly expressed in HCC tissues but was weakly positive in adjacent tissues $(p<0.001)$ (C). qRT-PCR results suggested the mRNA expression of PPARS in Bel $7402(p<0.001)$, SMMC-7721 $(p<0.001)$ and HepG2 cells $(p<0.05)$ was significantly higher than that of LO2 cell (D). WB results suggested that the protein expression of PPAR $\delta$ was increased in Bel $7402(p<0.001)$, SMMC-7721 $(p<0.001)$ and HepG2 cells $(p<0.001)$ compared with LO2 cell $(\mathbf{E})$
} 
A

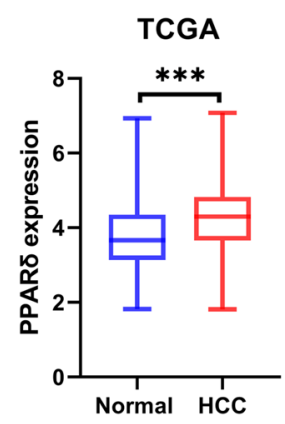

B

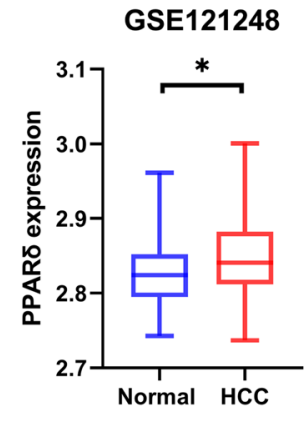

GSE36376

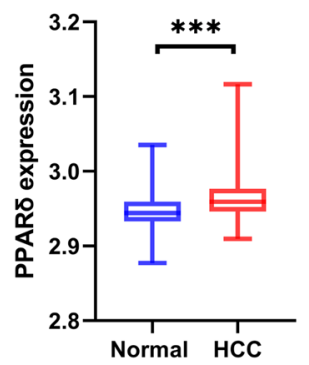

GSE62232

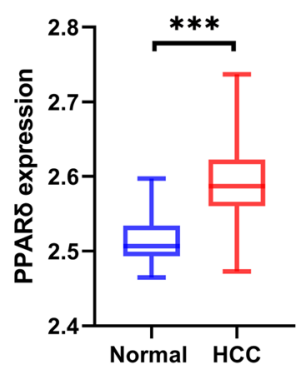

C

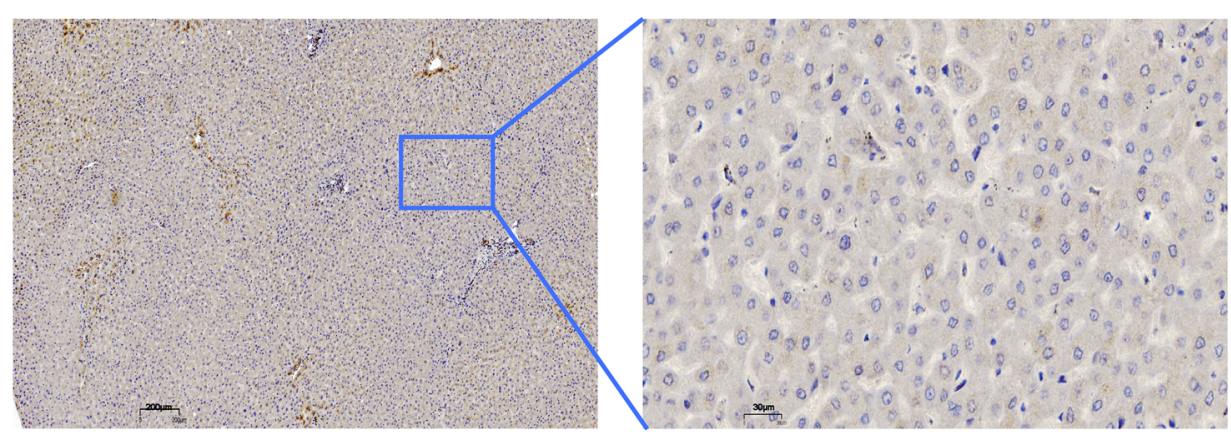

Adjacent normal tissues
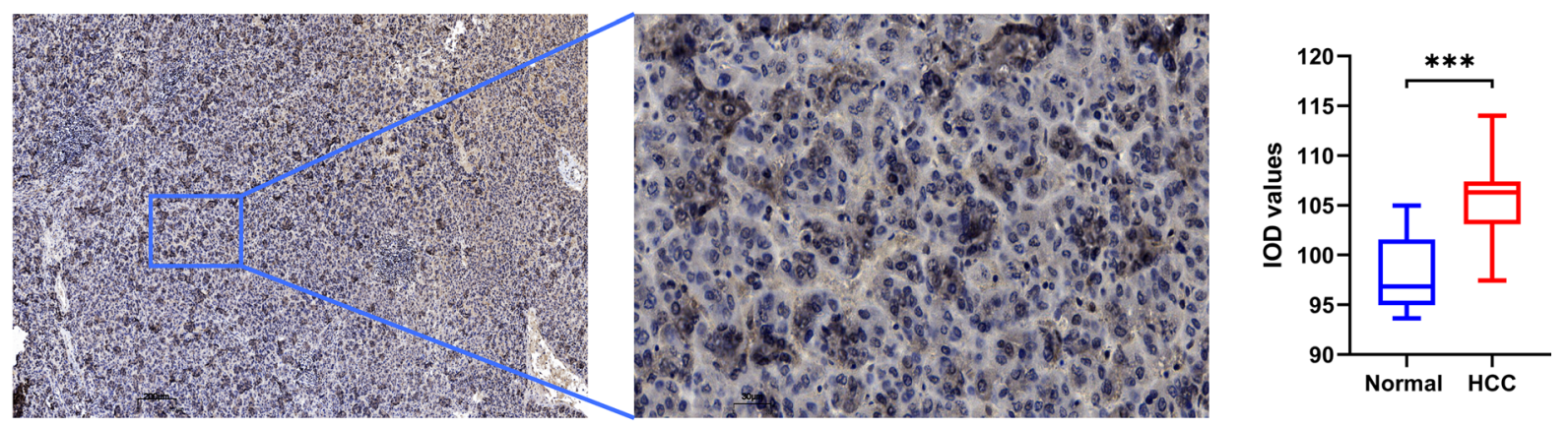

$\mathrm{HCC}$

D

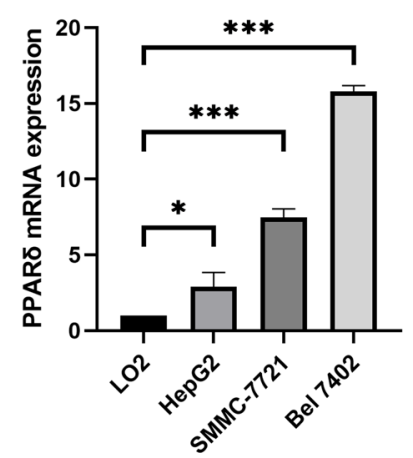

E
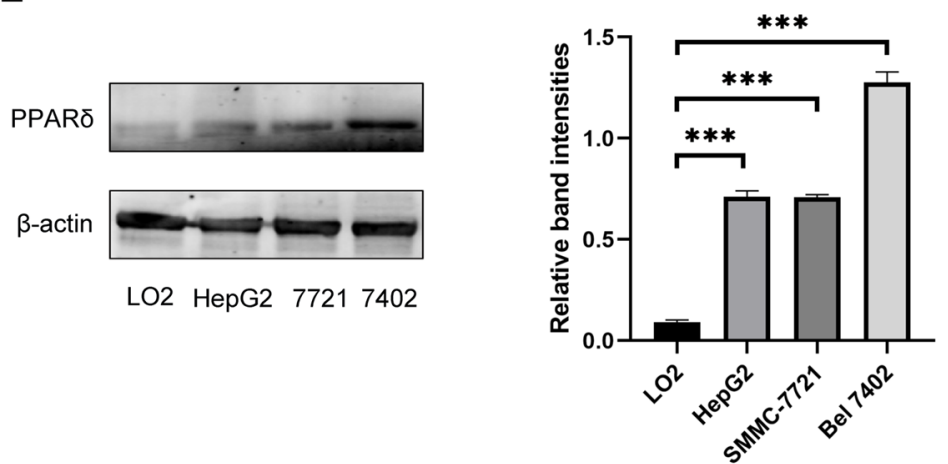

Fig. 1 (See legend on previous page.) 
Table 1 Clinicopathological characteristics of patients with HCC, retrieved from the TCGA database

\begin{tabular}{|c|c|c|c|}
\hline Category & Variables & Value & Percentage (\%) \\
\hline \multirow[t]{2}{*}{ Sex } & Male & 255 & 67.64 \\
\hline & Female & 122 & 32.36 \\
\hline \multirow[t]{2}{*}{ Age (years) } & Range & $16-90$ & / \\
\hline & Median & 59.45 & / \\
\hline \multirow[t]{5}{*}{ Stage } & 1 & 175 & 6.42 \\
\hline & $\|$ & 87 & 23.08 \\
\hline & III & 86 & 22.81 \\
\hline & IV & 5 & 1.33 \\
\hline & Unidentified & 24 & 6.36 \\
\hline \multirow[t]{5}{*}{ Tstage } & $\mathrm{T} 1$ & 185 & 49.07 \\
\hline & $\mathrm{T} 2$ & 95 & 25.20 \\
\hline & $\mathrm{T} 3$ & 81 & 21.49 \\
\hline & $\mathrm{T} 4$ & 13 & 3.45 \\
\hline & TX & 3 & 0.79 \\
\hline \multirow[t]{3}{*}{ Lymph node status } & NO & 257 & 68.17 \\
\hline & N1 & 4 & 1.06 \\
\hline & $\mathrm{Nx}$ & 116 & 30.77 \\
\hline \multirow[t]{3}{*}{ Metastatic } & Mo & 272 & 72.75 \\
\hline & M1 & 4 & 1.06 \\
\hline & $M X$ & 101 & 26.19 \\
\hline \multirow[t]{5}{*}{ Grade } & G1 & 55 & $14 . .59$ \\
\hline & G2 & 180 & 47.75 \\
\hline & G3 & 124 & 32.89 \\
\hline & G4 & 13 & 3.45 \\
\hline & Unidentified & 5 & 1.32 \\
\hline
\end{tabular}

p-GSK3 $\beta$ and Cyclin D1. GSK3787 had an antagonistic effect on these proteins (Fig. 5A-F). All these data indicate that PPAR $\delta$ could partially activated the PI3K-AKT pathway (Fig. 5G).

\section{Immune relevance of PPAR $\delta$}

In order to explore the role of PPAR $\delta$ in the TME, we calculated the infiltration of immune cells in HCC samples by means of CIBERSORT tool. Next, we analyzed the relationship between the expression level of PPAR $\delta$ and immune cell content. The analysis revealed that PPAR $\delta$ expression had a positive correlation with the infiltration of dendritic activated cells (Fig. 6A), regulatory $\mathrm{T}$ cells (Fig. 6B), neutrophils (Fig. 6C), plasma cells (Fig. 6D), CD4 memory resting $\mathrm{T}$ cells (Fig. 6E), follicular helper T cells (Fig. 6F) and a negative correlation with the infiltration of gamma delta T cells (Fig. 6G), resting NK cells (Fig. 6H), activated NK cells (Fig. 6I), resting mast cells (Fig. 6J), and M2 macrophages (Fig. 6K).

\section{Discussion}

The role of PPAR $\delta$ as oncogenic factor or tumor suppressor factor is still controversial, which is influenced by tumor types and experimental methods $[15,17,20$, 24-26]. In gastric cancer, researchers found that overexpression of PPAR $\delta$ in the villin promoter of mice quiescent gastric progenitor cells promoted the occurrence of spontaneously invasive gastric adenocarcinomas [16]. In addition, they found that the expression of PPAR $\delta$ was significantly increased in human gastric tissues and was associated with poor prognosis [16]. In colon cancer, it was revealed that the expression of PPAR $\delta$ in human colon cancer tissues was significantly higher than that of adenoma polyps and normal intestinal mucosa. Its cancer-promoting mechanism has also been further explored in colorectal tumor cell lines and colon cancer mouse models [17, 27-29]. Similarly, some teams have reached the opposite conclusion [30,31]. The latest research pointed out that PPAR $\delta$ promoted liver metastasis of colon cancer by inducing the expansion of colonic stem cells [32]. In melanoma, study has shown that PPAR $\delta$ activation modulated the migration and invasion of melanoma cells by up-regulating Snail expression [33]. In this study, analysis based on the TCGA and GEO transcriptome data revealed a significantly increased expression of PPAR $\delta$ in HCC compared with normal liver tissues. What's more, the immunohistochemical analysis of the HCC tissues in our medical facility demonstrated its overexpression at the protein level. The significant clinical relevance of PPAR $\delta$, including TNM stage and pathology classification, was also disclosed. Especially, K-M survival curves for OS, DSS, PFS and Cox analysis suggested that high expression of PPAR $\delta$ displayed a significant unfavorable prognosis. The high expression of PPARS in HCC cells was also verified. In cell function experiments, we proved that PPAR $\delta$ can promote the proliferation and migration of HCC cells. Consequently, digging into the PPAR $\delta$ related mechanisms may contribute to give full play to its biological and pharmacological effect.

EMT had a positive effect on tumor invasion and distant metastasis, in which epithelial cells lost intercellular adhesion and obtained mesenchymal properties $[34,35]$. Studies have shown that the transcription factor Snail was one of the main EMT-inducing factors in HCC and was related to the prognosis of HCC [36]. Snail binded to three E-boxes in the human E-cadherin promoter, thereby suppressed transcription of E-cadherin $[37,38]$ Therefore, we determined the expression of these two EMT markers. The results revealed that 


\section{A} Cancer: LIHC

sample stage 审 Stage I 宊 Stage II 审 Stage III 审 Stage IV

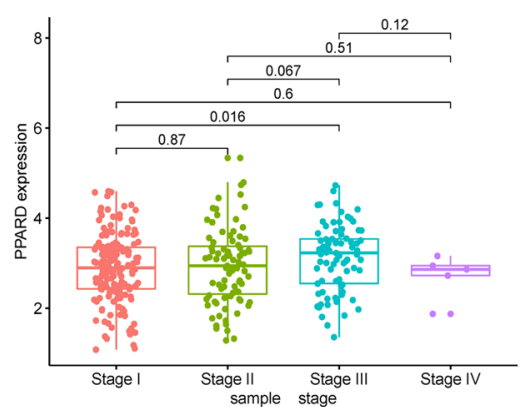

D

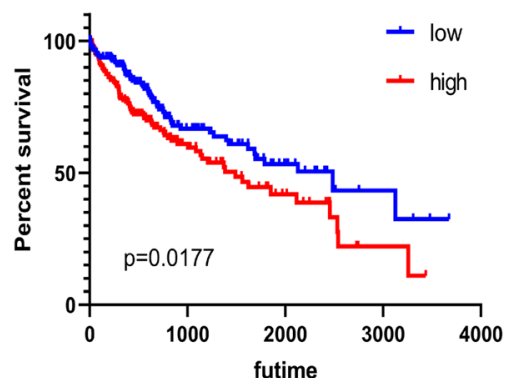

B Cancer: LIHC

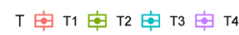

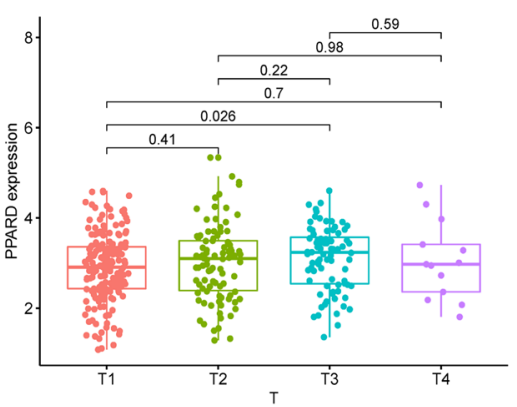

E

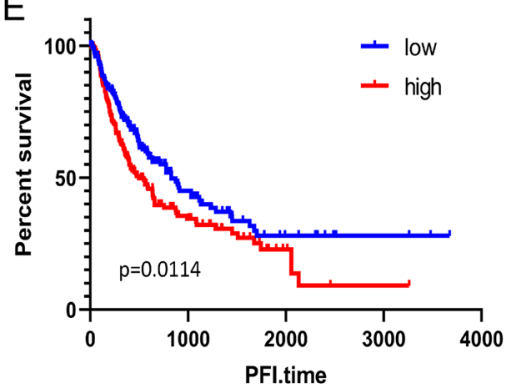

C

Cancer: LIHC

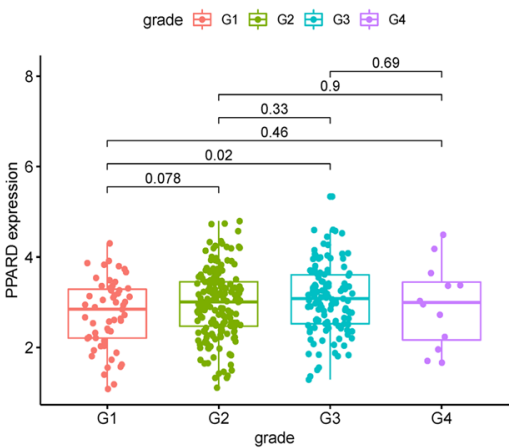

F

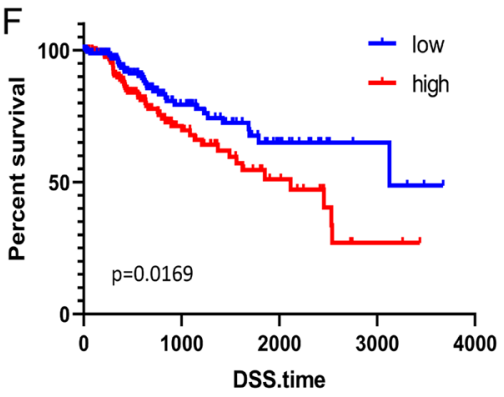

G

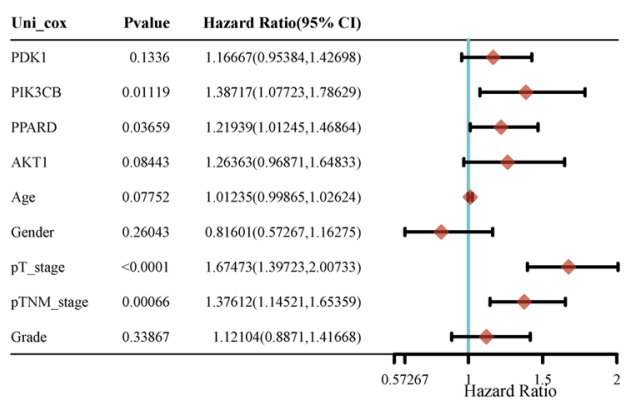

$\mathrm{H}$

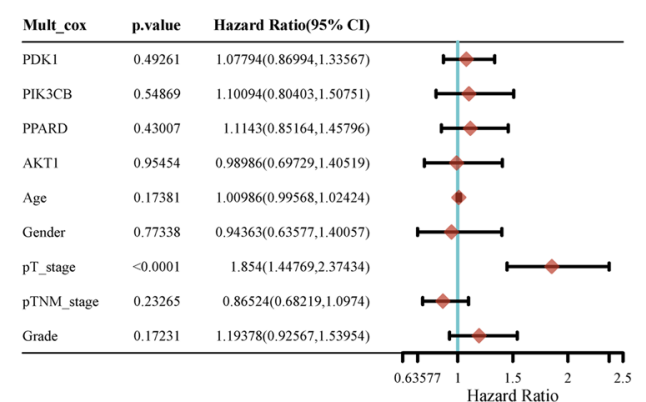

Fig. 2 Association of PPAR $\delta$ expression and clinical characteristics. The expression of PPAR $\delta$ increased gradually with the progress of clinical stage, T stage and grade $(\mathbf{A}-\mathbf{C})$. The low PPAR $\delta$ expression group had significantly higher over survival (OS) rate $(p=0.0177)(\mathbf{D})$, PFS (progression free survival) rate $(p=0.0114)$ (E) and DSS (disease specific survival) rate $(p=0.0169)(\mathbf{F})$ than that of high PPAR $\delta$ expression group. Cox regression analyses suggested that PPARS, PI3K, PDK1, AKT1 were risk factors for poor prognosis of HCC $(H R>1)(\mathbf{G}, \mathbf{H})$

activation of PPAR $\delta$ up-regulated the expression of the epithelial marker Snail and down-regulated the expression of the mesenchymal marker E-cadherin. The "angiogenic switch" effect of PPAR $\delta$ has been verified by a large amount of literature [18]. In our study, we also found that
HCC cells treated with agonist expressed more VEGFA. Taken together, PPAR $\delta$ may induce EMT by regulating Snail expression and promote angiogenesis through upregulation of VEGFA expression.

(See figure on next page.)

Fig. 3 Effect of PPARS on proliferation of HCC cell. PPARS agonist GW501516 increased mRNA expression of PPAR $\delta$ target gene Angpt|4. while antagonist GSK3787 reversed its up-regulated expression (A, B). The CCK8 assay results revealed that the agonist promoted HCC cells proliferation in a dose-dependent manner (C, D) and GSK3787 reversed the proliferation effect of GW501516 (E, F). EdU staining assay results showed that the intervention of GW501516 increased the ratio of proliferating cells, and GSK3787 reversed the proliferation effect of GW501516 in Bel 7402 cell line $(\mathbf{G}, \mathbf{I})$ and SMMC-7721 cell line $(\mathbf{H}, \mathbf{J})$ 
A

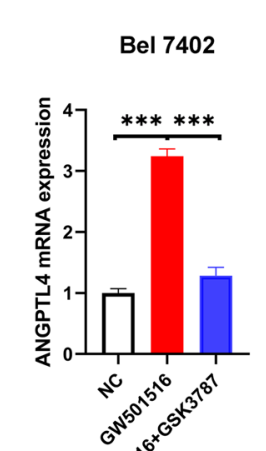

B
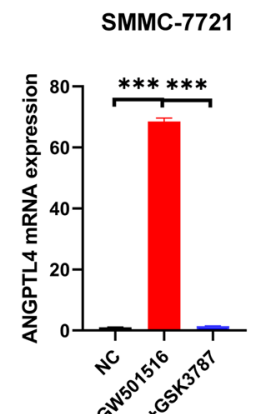

G

7402 control
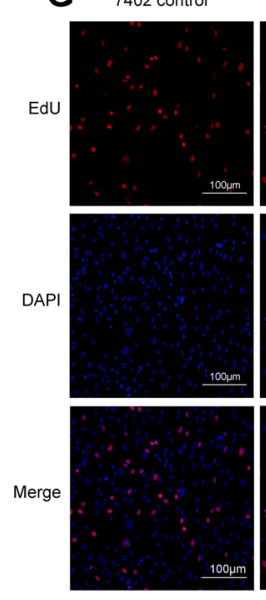

I
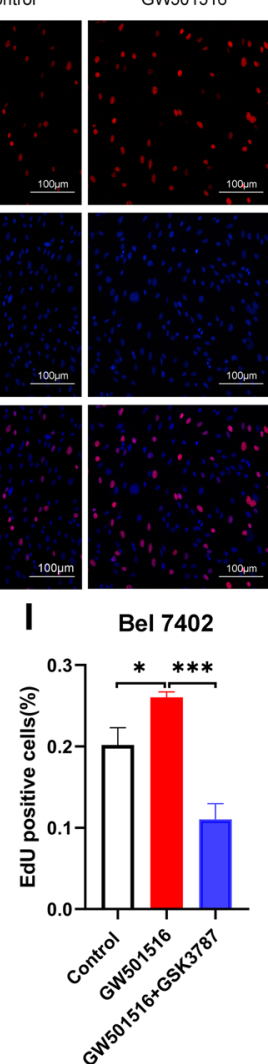

C

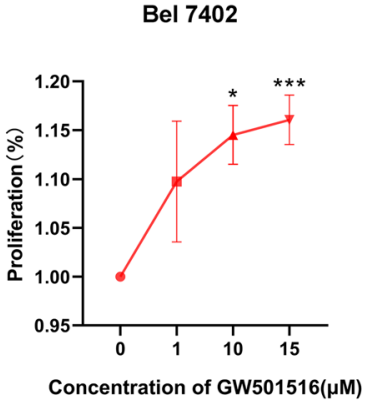

D

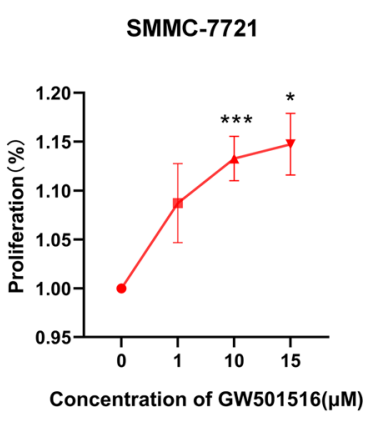

E

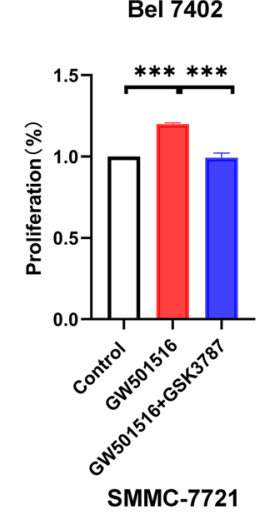

$\mathbf{F}$

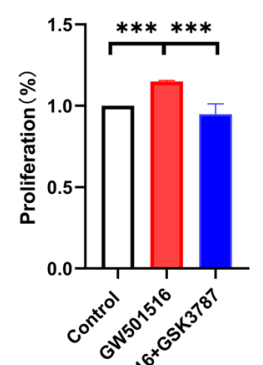

Fig. 3 (See legend on previous page.)
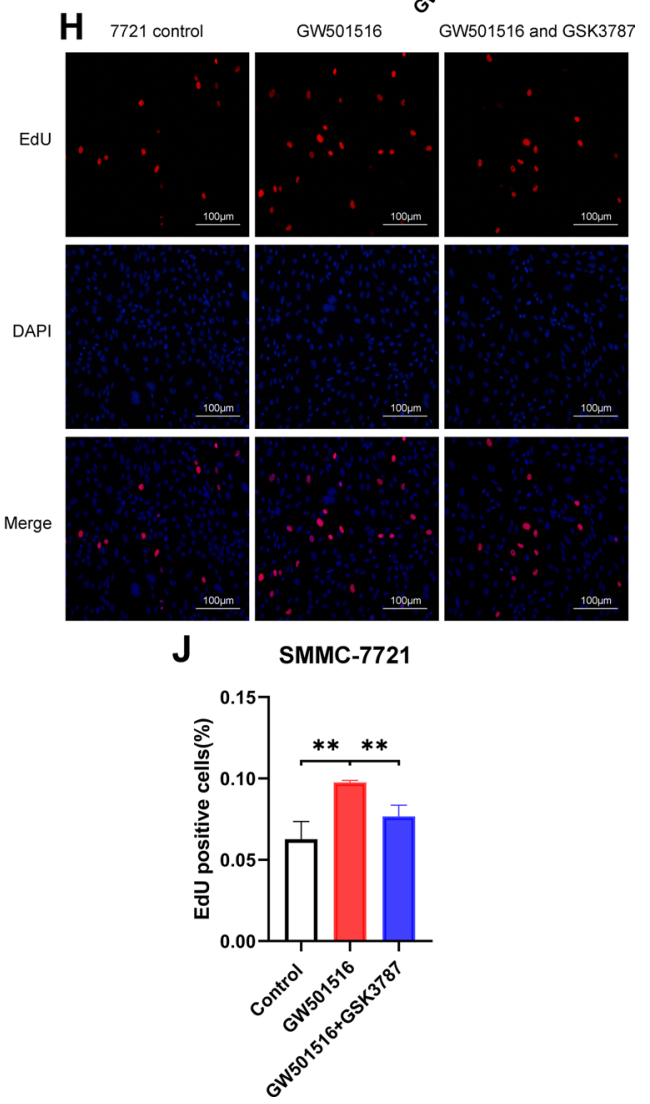

GW501516 and GSK3787
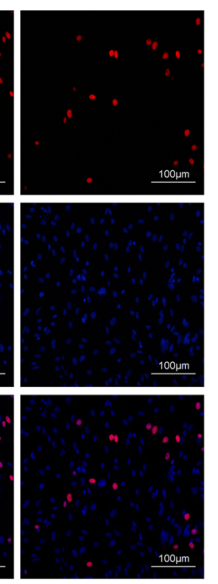

H 7721 control 
A

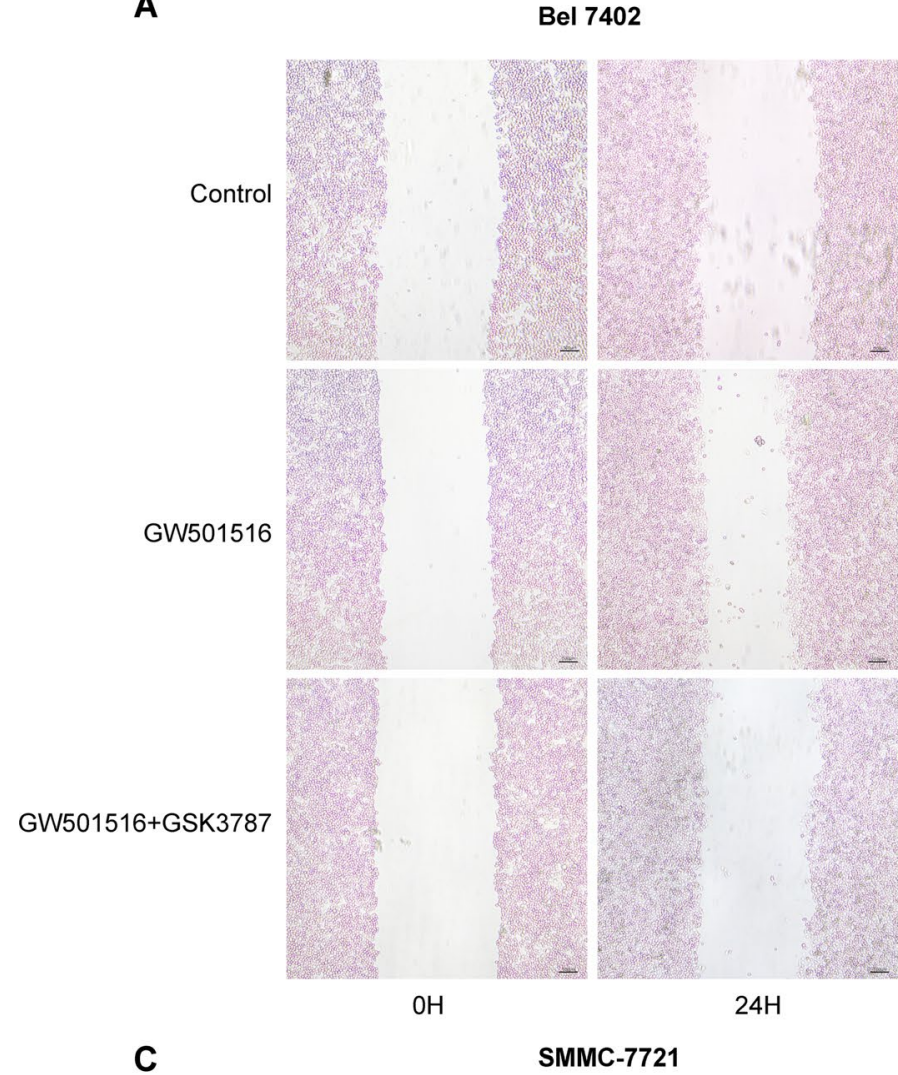

C

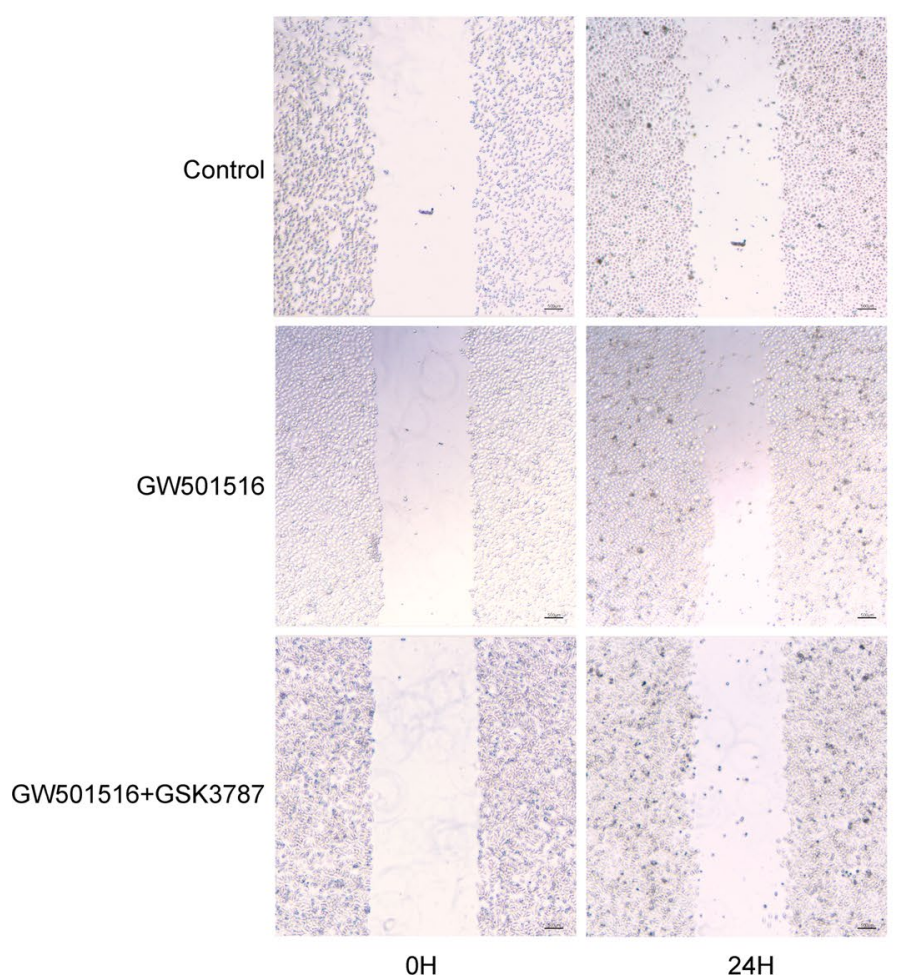

Wound Healing Assay of Bel-7402

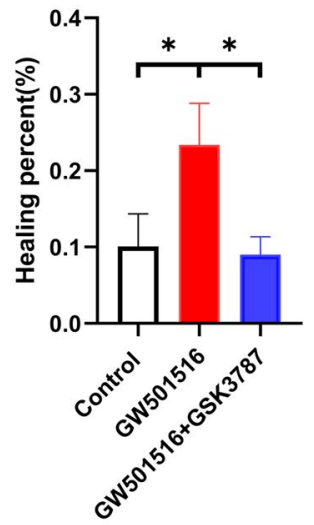

B

E-cadherin

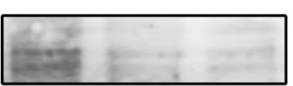

Snail

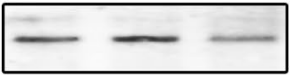

VEGFA

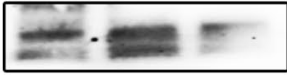

$\beta$-actin

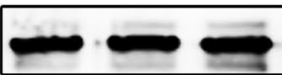

NC GW501516 GW501516+GSK3787

Wound Healing Assay of SMMC-7721

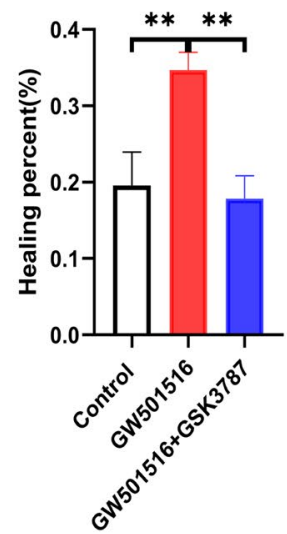

D
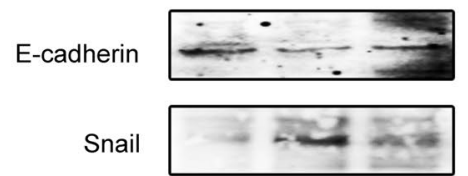

VEGFA

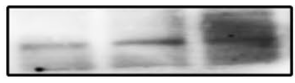

$\beta$-actin

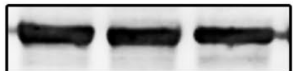

NC GW501516 GW501516+GSK3787

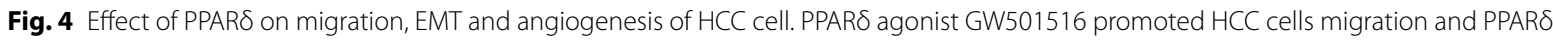
antagonist GSK3787 reversed the effect of GW501516 (A, C). GW501516 reduced the expression of E-cadherin, increased the expression of Snail and VEGFA, the antagonist abolished the effect (B, D) 


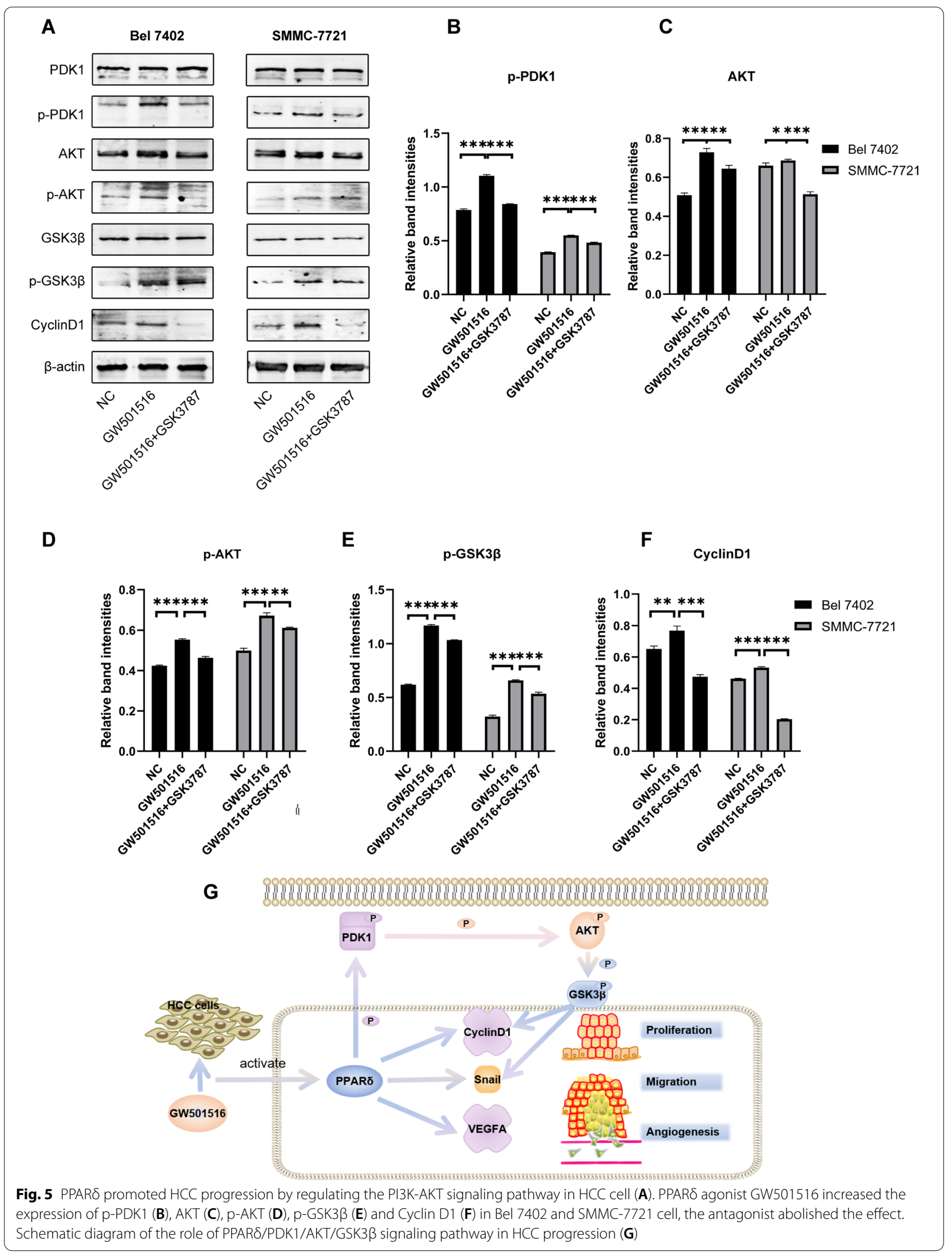




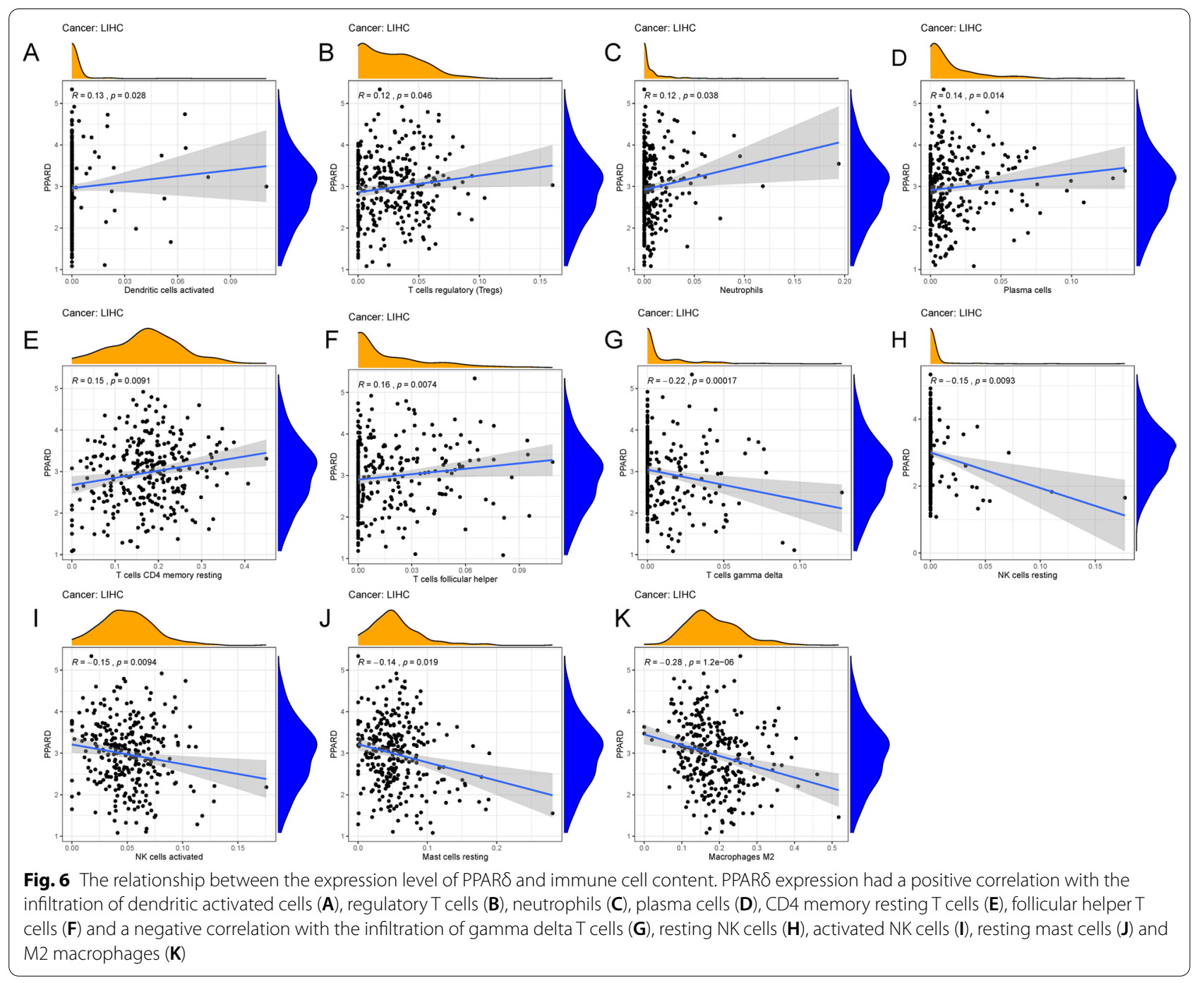

The PI3K-AKT pathway was a key regulatory center that regulated cell growth, metabolism, proliferation, survival, transcription and protein synthesis. Activated PI3K catalyzed the 3-hydroxyl phosphorylation of PIP2 to generate PIP3, which acted as a second messenger to recruit PDK1 and AKT proteins to the plasma membrane. PDK1 can phosphorylate the threonine $\left(\mathrm{Thr}^{308}\right)$ of the AKT protein, and the additional phosphorylation of mTORC2 at the c-terminal domain of serine 473 $\left(\mathrm{Ser}^{473}\right)$ resulted in complete activation of AKT. The activated AKT will further activate downstream signal pathways $[39,40]$. Currently, PI3K-AKT pathway have got a major focus of attention in tumor progression, inhibitors of this pathway have brought new horizons for targeted tumor therapy [41]. The activation of PI3K-AKT pathway was associated with the progression and metastasis of HCC [42]. One study demonstrated that PPAR $\delta$ promoted proliferation and inhibited apoptosis through the
PI3K-AKT pathway in non-small cell lung cancer [22]. Another study also revealed that PPAR $/ \mathrm{PDK} 1 / \mathrm{PTEN} /$ AKT/GSK3 $\beta /$ Cyclin D1 pathway was involved in the proliferation of keratinocytes in cholesteatoma [23]. Therefore, we detected the expression of PI3K-AKT pathway related markers in agonist-intervened HCC cells. We could find that the expression of p-PDK1, AKT, p-AKT, and the targeted effector molecule p-GSK3 $\beta$ and Cyclin D1 has increased. PDK1 was identified as a target gene for PPAR $[43,44]$. Phosphorylated PDK1 can promote the activation of AKT, thereby inhibiting the function of GSK3 $\beta$ through phosphorylation at Ser 9. The inactivation of GSK-3 $\beta$ abolished its degrading effect on cyclin D1, and the expression of cyclin D1 was up-regulated [45]. Besides, the suppression of GSK3 $\beta$ induced by AKT could increase the stability of Snail and promote the occurrence of EMT [46]. In summary, PPAR $\delta$ may promote $\mathrm{HCC}$ progression by partially activating the 
PI3K-AKT pathway. However, more detailed regulatory network needs further experimental exploration.

It is well known that not only the tumor cells themselves but also the TME composed of stromal cells, immune cells, extracellular matrix (ECM), cytokines, chemokines, growth factors, and enzymes hold an important role in tumor development. We further analyzed the relationship between the expression of PPAR $\delta$ and the content of infiltrating immune cells in HCC tissues. Among the immune cells fighting tumors, effector $\mathrm{T}$ cells and NK cells play a major role. However, metabolic changes in the TME impede the maintenance of $T$ cell normal function, leading to the formation of immune tolerance. Literature has affirmed that PPAR $\alpha$ and PPAR $\delta$ could enhance the persistence of memory CD $8+\mathrm{T}$ cells by targeting the fatty acid oxidation pathway, thereby improving the efficacy of adoptive cell therapy [47]. Regarding NK cells, a recent study indicated that obesity induced PPAR-driven lipid accumulation in NK cells, leading to complete "paralysis" of cellular metabolism and trafficking. Targeting PPAR $\alpha / \delta$ may restore NK cells function and cytotoxicity [48]. Unlike effector $\mathrm{T}$ cells, Tregs cells maintained their active proliferative state through the uptake of lactic acid [49]. Recently, a study proposed the hypothesis that CD36 acted on the PPAR $\delta$ pathway to fine-tune mitochondrial fitness and thus programed Treg cells to adapt to the lactic acid-enriched TME. Targeting this metabolic pathway to deplete Treg cells showed great antitumor therapeutic potential [50]. In our immune relevance analysis, the expression level of PPAR $\delta$ was correlated with the infiltration of CD $4+\mathrm{T}$ cells, Treg cells and NK cells, which gives us a hint to thoroughly explore the value of PPAR $\delta$ pathway in T cell and NK cell metabolism about HCC. M2 polarization of tumor-associated macrophages (TAM) was considered as a marker of tumor progression in HCC [51]. Similarly, PPAR $\delta$ was believed to be an important downstream regulator for the alternative activation of TAM in HCC caused by SIRT4 gene silencing [52]. Our research suggested that PPAR $\delta$ expression was significantly related to macrophage subtypes. Taken together, the expression of PPAR $\delta$ had a close correlation with several immune cells in HCC tumor microenvironment.

There are some limitations in our study. First, our hypothesis obtained from in vitro experiments lacks support from in vivo results. Second, the composition of cells in HCC tissues are complex, other cellular components in the TME, such as immune cells and stromal cells, are equally critical to tumor progression. our study only verified the regulatory role of PPAR $\delta$ in HCC cells. Therefore, further exploration is badly required.

\section{Conclusion}

In summary, our results illustrated that PPAR $\delta$ expression was significantly higher in HCC tissues compared to normal liver tissues and was related to progression and poor prognosis of HCC. PPAR $\delta$ has been shown increased expression in HCC cells and promoted the proliferation and invasion of HCC cells via PDK1/AKT/ GSK3 $\beta$ signaling pathway. Further, the level of PPAR $\delta$ expression was correlated with the infiltration of various immune cells.

\section{Abbreviations \\ HCC: Hepatocellular carcinoma; PPARa: Peroxisome proliferator activated receptor alpha; PPARY: Peroxisome proliferator activated receptor gamma; PPARS: Peroxisome proliferator activated receptor delta; AKT: Protein kinase B; PI3K: Phosphoinositide 3-kinase; PDK1: Pyruvate dehydrogenase kinase 1; GSK3B: Glycogen synthase kinase 3 beta; TCGA-LIHC: The Cancer Genome Atlas-liver hepatocellular carcinoma dataset.}

\section{Acknowledgements}

Not applicable.

\section{Authors' contributions}

WH provided the main contribution to this work. WH, NW, RK, WB were responsible for analyzing data and writing the manuscript. This manuscript is approved by all authors for publication. All authors have read and approved the final manuscript.

\section{Funding}

This study was supported by the National Nature Science Foundation of China (No. 81770518) to Jie Lu.

\section{Availability of data and materials}

The transcriptome data and clinical data in the study are available at the following hyperlinks: 1.The Cancer Genome Atlas, (TCGA, https://tcga-data.nci. nih.gov/tcga/); 2.Gene Expression Omnibus, (GEO, http://www.ncbi.nlm.nih. gov/geo/).

\section{Declarations}

\section{Ethics approval and consent to participate}

This study was approved by the human study ethics committees at Shanghai Tenth People's Hospital (ID SHSY-IEC-4.1/20-261/01). All patients provided written informed consent for participation in the study. Specimens were handled in accordance with legal and ethical regulations.

\section{Consent for publication}

Not applicable.

\section{Competing interests}

The authors declare that they have no competing interests.

\section{Author details}

'Department of Gastroenterology, Shanghai Tenth People's Hospital, Tongji University School of Medicine, Shanghai, China. ${ }^{2}$ Department of Gastroenterology, Gongli Hospital of Shanghai Pudong New Area, Shanghai, China.

Received: 16 November 2021 Accepted: 31 January 2022

Published online: 12 February 2022

References

1. Sung H, Ferlay J, Siegel RL, Laversanne M, Soerjomataram I, Jemal A, et al. Global cancer statistics 2020: GLOBOCAN estimates of incidence and 
mortality worldwide for 36 cancers in 185 countries. CA Cancer J Clin. 2021. https://doi.org/10.3322/caac.21660.

2. Wild CPWE, Stewart BW. World cancer report: cancer research for cancer prevention. Lyon: International Agency for Research on Cancer; 2020. p. 34-43.

3. Patel K, Lamm R, Altshuler P, Dang H, Shah AP. Hepatocellular carcinomathe influence of immunoanatomy and the role of immunotherapy. Int J Mol Sci. 2020. https://doi.org/10.3390/ijms21186757.

4. Auwerx J, Baulieu E, Beato M, Becker-Andre M, Burbach PH, Camerino G, Chambon P, Cooney A, Dejean A, Dreyer C, Evans RM. A unified nomenclature system for the nuclear receptor superfamily. Cell. 1999;97(2):161-3.

5. Chawla A, Repa JJ, Evans RM, Mangelsdorf DJ. Nuclear receptors and lipid physiology: opening the X-files. Science (New York, NY). 2001;294(5548):1866-70.

6. Grygiel-Górniak B. Peroxisome proliferator-activated receptors and their ligands: nutritional and clinical implications-a review. Nutr J. 2014;13:17.

7. Laganà AS, Vitale SG, Nigro A, Sofo V, Salmeri FM, Rossetti P, et al. Pleiotropic actions of peroxisome proliferator-activated receptors (PPARs) in dysregulated metabolic homeostasis, inflammation and cancer: current evidence and future perspectives. Int J Mol Sci. 2016. https://doi.org/10. 3390/ijms17070999.

8. Kong R, Wang N, Han W, Bao W, Lu J. Fenofibrate exerts antitumor effects in colon cancer via regulation of DNMT1 and CDKN2A. PPAR Res. 2021;2021:6663782

9. Castelli V, Catanesi M, Alfonsetti M, Laezza C, Lombardi F, Cinque B, et al. PPARa-selective antagonist GW6471 inhibits cell growth in breast cancer stem cells inducing energy imbalance and metabolic stress. Biomedicines. 2021. https://doi.org/10.3390/biomedicines9020127.

10. Augimeri G, Gelsomino L, Plastina P, Giordano C, Barone I, Catalano S, et al. Natural and synthetic PPARY ligands in tumor microenvironment: a new potential strategy against breast cancer. Int J Mol Sci. 2020. https:// doi.org/10.3390/ijms21249721.

11. Yang Y, Zhao LH, Huang B, Wang RY, Yuan SX, Tao QF, et al. Pioglitazone, a PPARY agonist, inhibits growth and invasion of human hepatocellular carcinoma via blockade of the rage signaling. Mol Carcinog. 2015;54(12):1584-95.

12. Augimeri G, Giordano C, Gelsomino L, Plastina P, Barone I, Catalano S, et al. The role of PPARy ligands in breast cancer: from basic research to clinical studies. Cancers. 2020. https://doi.org/10.3390/cancers 12092623.

13. Skrypnyk N, Chen X, Hu W, Su Y, Mont S, Yang S, et al. PPARa activation can help prevent and treat non-small cell lung cancer. Can Res. 2014;74(2):621-31.

14. Mirza AZ, Althagafi II, Shamshad H. Role of PPAR receptor in different diseases and their ligands: physiological importance and clinical implications. Eur J Med Chem. 2019;166:502-13.

15. Martín-Martín N, Zabala-Letona A, Fernández-Ruiz S, Arreal L, Camacho $\mathrm{L}$, Castillo-Martin M, et al. PPARS elicits ligand-independent repression of trefoil factor family to limit prostate cancer growth. Can Res. 2018;78(2):399-409.

16. Zuo X, Deguchi Y, Xu W, Liu Y, Li HS, Wei D, et al. PPARD and interferon gamma promote transformation of gastric progenitor cells and tumorigenesis in mice. Gastroenterology. 2019;157(1):163-78.

17. Liu Y, Deguchi Y, Tian R, Wei D, Wu L, Chen W, et al. Pleiotropic effects of PPARD accelerate colorectal tumorigenesis, progression, and invasion. Can Res. 2019;79(5):954-69.

18. Wagner N, Wagner KD. PPAR beta/delta and the hallmarks of cancer. Cells. 2020. https://doi.org/10.3390/cells9051133.

19. Zuo X, Xu W, Xu M, Tian R, Moussalli MJ, Mao F, et al. Metastasis regulation by PPARD expression in cancer cells. JCI Insight. 2017;2(1): e91419.

20. Wagner KD, Du S, Martin L, Leccia N, Michiels JF, Wagner N. Vascular PPARß/ठ promotes tumor angiogenesis and progression. Cells. 2019. https://doi.org/10.3390/cells8121623.

21. Newman AM, Liu CL, Green MR, Gentles AJ, Feng W, Xu Y, et al. Robust enumeration of cell subsets from tissue expression profiles. Nat Methods. 2015;12(5):453-7.

22. Pedchenko TV, Gonzalez AL, Wang D, DuBois RN, Massion PP. Peroxisome proliferator-activated receptor beta/delta expression and activation in lung cancer. Am J Respir Cell Mol Biol. 2008;39(6):689-96.
23. Zhang C, Liu YW, Chi Z, Chen B. Ligand-activated peroxisome proliferatoractivated receptor $\beta / \delta$ facilitates cell proliferation in human cholesteatoma keratinocytes. PPAR Res. 2020;2020:8864813.

24. Luo W, He D, Zhang J, Ma Z, Chen K, Lv Z, et al. Knockdown of PPARS induces VEGFA-mediated angiogenesis via interaction with ERO1A in human colorectal cancer. Front Oncol. 2021;11:713892.

25. Her NG, Jeong SI, Cho K, Ha TK, Han J, Ko KP, et al. PPARS promotes oncogenic redirection of TGF- $\beta 1$ signaling through the activation of the ABCA1-Cav1 pathway. Cell Cycle (Georgetown, Tex). 2013;12(10):1521-35.

26. Yang L, Zhou J, Ma Q, Wang C, Chen K, Meng W, et al. Knockdown of PPAR $\delta$ gene promotes the growth of colon cancer and reduces the sensitivity to bevacizumab in nude mice model. PloS ONE. 2013;8(4): e60715.

27. Wang D, Wang H, Guo Y, Ning W, Katkuri S, Wahli W, et al. Crosstalk between peroxisome proliferator-activated receptor delta and VEGF stimulates cancer progression. Proc Natl Acad Sci USA. 2006;103(50):19069-74.

28. Zhou D, Jin J, Liu Q, Shi J, Hou Y. PPARS agonist enhances colitis-associated colorectal cancer. Eur J Pharmacol. 2019;842:248-54.

29. Gupta RA, Wang D, Katkuri S, Wang H, Dey SK, DuBois RN. Activation of nuclear hormone receptor peroxisome proliferator-activated receptordelta accelerates intestinal adenoma growth. Nat Med. 2004;10(3):245-7.

30. Foreman JE, Chang WC, Palkar PS, Zhu B, Borland MG, Williams JL, et al. Functional characterization of peroxisome proliferator-activated receptor$\beta / \delta$ expression in colon cancer. Mol Carcinog. 2011;50(11):884-900.

31. Marin HE, Peraza MA, Billin AN, Willson TM, Ward JM, Kennett MJ, et al. Ligand activation of peroxisome proliferator-activated receptor beta inhibits colon carcinogenesis. Can Res. 2006;66(8):4394-401.

32. Wang D, Fu L, Wei J, Xiong Y, DuBois RN. PPARS mediates the effect of dietary fat in promoting colorectal cancer metastasis. Can Res. 2019;79(17):4480-90.

33. Ham SA, Yoo T, Hwang JS, Kang ES, Lee WJ, Paek KS, et al. Ligand-activated PPAR $\delta$ modulates the migration and invasion of melanoma cells by regulating Snail expression. Am J Cancer Res. 2014;4(6):674-82.

34. Thiery JP. Epithelial-mesenchymal transitions in tumour progression. Nat Rev Cancer. 2002;2(6):442-54.

35. Puisieux A, Brabletz T, Caramel J. Oncogenic roles of EMT-inducing transcription factors. Nat Cell Biol. 2014;16(6):488-94.

36. Yang MH, Chen CL, Chau GY, Chiou SH, Su CW, Chou TY, et al. Comprehensive analysis of the independent effect of twist and snail in promoting metastasis of hepatocellular carcinoma. Hepatology (Baltimore, MD). 2009;50(5):1464-74.

37. Batlle E, Sancho E, Francí C, Domínguez D, Monfar M, Baulida J, et al. The transcription factor snail is a repressor of $\mathrm{E}$-cadherin gene expression in epithelial tumour cells. Nat Cell Biol. 2000;2(2):84-9.

38. Cano A, Pérez-Moreno MA, Rodrigo I, Locascio A, Blanco MJ, del Barrio $M G$, et al. The transcription factor snail controls epithelial-mesenchymal transitions by repressing E-cadherin expression. Nat Cell Biol. 2000;2(2):76-83.

39. De Luca A, Maiello MR, D'Alessio A, Pergameno M, Normanno N. The RAS/RAF/MEK/ERK and the PI3K/AKT signalling pathways: role in cancer pathogenesis and implications for therapeutic approaches. Expert Opin Ther Targets. 2012;16(Suppl 2):S17-27.

40. Chan CH, Jo U, Kohrman A, Rezaeian AH, Chou PC, Logothetis C, et al. Posttranslational regulation of Akt in human cancer. Cell Biosci. 2014:4(1):59.

41. Brown JS, Banerji U. Maximising the potential of AKT inhibitors as anticancer treatments. Pharmacol Ther. 2017:172:101-15.

42. Rahmani F, Ziaeemehr A, Shahidsales S, Gharib M, Khazaei M, Ferns GA, et al. Role of regulatory miRNAs of the PI3K/AKT/mTOR signaling in the pathogenesis of hepatocellular carcinoma. J Cell Physiol. 2020;235(5):4146-52.

43. Schug TT, Berry DC, Shaw NS, Travis SN, Noy N. Opposing effects of retinoic acid on cell growth result from alternate activation of two different nuclear receptors. Cell. 2007:129(4):723-33.

44. Di-Poï N, Tan NS, Michalik L, Wahli W, Desvergne B. Antiapoptotic role of PPARbeta in keratinocytes via transcriptional control of the Akt 1 signaling pathway. Mol Cell. 2002;10(4):721-33.

45. Chang F, Lee JT, Navolanic PM, Steelman LS, Shelton JG, Blalock WL, et al. Involvement of PI3K/Akt pathway in cell cycle progression, apoptosis, and neoplastic transformation: a target for cancer chemotherapy. Leukemia. 2003;17(3):590-603. 
46. Zhou BP, Deng J, Xia W, Xu J, Li YM, Gunduz M, et al. Dual regulation of Snail by GSK-3beta-mediated phosphorylation in control of epithelialmesenchymal transition. Nat Cell Biol. 2004;6(10):931-40.

47. Saibil SD, St Paul M, Laister RC, Garcia-Batres CR, Israni-Winger K, Elford $A R$, et al. Activation of peroxisome proliferator-activated receptors a and $\delta$ synergizes with inflammatory signals to enhance adoptive cell therapy. Can Res. 2019;79(3):445-51.

48. Michelet X, Dyck L, Hogan A, Loftus RM, Duquette D, Wei K, et al. Metabolic reprogramming of natural killer cells in obesity limits antitumor responses. Nat Immunol. 2018;19(12):1330-40.

49. Watson MJ, Vignali PDA, Mullett SJ, Overacre-Delgoffe AE, Peralta RM, Grebinoski S, et al. Metabolic support of tumour-infiltrating regulatory T cells by lactic acid. Nature. 2021. https://doi.org/10.1038/s41586-020-03045-2.

50. Wang H, Franco F, Tsui YC, Xie X, Trefny MP, Zappasodi R, et al. CD36mediated metabolic adaptation supports regulatory $T$ cell survival and function in tumors. Nat Immunol. 2020;21 (3):298-308.

51. Solinas G, Schiarea S, Liguori M, Fabbri M, Pesce S, Zammataro L, et al. Tumor-conditioned macrophages secrete migration-stimulating factor: a new marker for M2-polarization, influencing tumor cell motility. J Immunol. 2010;185(1):642-52.

52. Li Z, Li H, Zhao ZB, Zhu W, Feng PP, Zhu XW, et al. SIRT4 silencing in tumor-associated macrophages promotes HCC development via PPAR $\delta$ signalling-mediated alternative activation of macrophages. J Exp Clin Cancer Res. 2019;38(1):469.

\section{Publisher's Note}

Springer Nature remains neutral with regard to jurisdictional claims in published maps and institutional affiliations.

- fast, convenient online submission

- thorough peer review by experienced researchers in your field

- rapid publication on acceptance

- support for research data, including large and complex data types

- gold Open Access which fosters wider collaboration and increased citations

- maximum visibility for your research: over $100 \mathrm{M}$ website views per year

At BMC, research is always in progress.

Learn more biomedcentral.com/submissions 